\title{
Civilisations
}

Revue internationale d'anthropologie et de sciences

humaines

40-1 | 1991

L'Asie et le Pacifique

\section{Les relations internationales dans le Pacifique occidental}

Introduction

International relations in the Western Pacific

Marthe Engelborghs-Bertels

\section{(2) OpenEdition}

Journals

Édition électronique

URL : http://journals.openedition.org/civilisations/1674

DOI : $10.4000 /$ civilisations. 1674

ISSN : 2032-0442

Éditeur

Institut de sociologie de l'Université Libre de Bruxelles

\section{Édition imprimée}

Date de publication : 1 janvier 1992

Pagination : 9-24

ISBN : 2-87263-063-5

ISSN : 0009-8140

Référence électronique

Marthe Engelborghs-Bertels, «Les relations internationales dans le Pacifique occidental », Civilisations [En ligne], 40-1 | 1991, mis en ligne le 07 juillet 2009, consulté le 22 septembre 2020. URL : http:// journals.openedition.org/civilisations/1674; DOI : https://doi.org/10.4000/civilisations.1674 


\section{LES RELATIONS INTERNATIONALES DANS LE PACIFIQUE OCCIDENTAL}

Marthe ENGELBORGHS-BERTELS

La région que forme l'Asie baignée par l'Océan Pacifique, désignée souvent comme l'Asie-Pacifique, est considérée à cause de l'expansion économique du Japon et des pays qu'il a entraînés dans son sillage, comme destinée à un rôle essentiel, non seulement en tant que moteur du développement régional et exemple à imiter mais aussi comme futur pôle de décision dans les relations internationales en collaboration avec le versant oriental du Pacifique nord.

Le présent volume de la revue "Civilisations" ne cherche pas à décrire une culture ou un ensemble de cultures apparentées, il analyse comment se présentent les relations internationales dans une vaste région du monde, quels objectifs poursuivent les principaux acteurs et quels moyens sont mis en oeuvre pour les atteindre. Si une civilisation se définit par les valeurs qui déterminent les choix opérés par une culture parmi les techniques disponibles pour exploiter les ressources du territoire qu'elle anime, organiser son espace, encadrer sa population et assurer sa perennité, tout ce qui concerne la manière dont un pays ou un groupe de pays s'efforce d'assurer sa sécurité, son indépendance et sa puissance participe évidemment à ce que recouvre le titre de la présente revue.

Les stratégies internes axées tantôt sur la force des armes tantôt sur l'acquisition des armes de la puissance que sont le plein épanouissement des potentialités économiques et scientifiques de la nation comme les options prises en faveur d'un développement auto-centré ou à l'opposé en faveur de 
l'utilisation des avantages comparatifs et de l'interdépendance planétaire, entraînent des politiques étrangères différentes qu'infléchissent encore les circonstances, les changements des dirigeants et le degré de satisfaction des populations concernées. Les résultats obtenus par une ligne d'action déterminent la solidité, la longévité et le rayonnement d'un Etat ou d'un regroupement d'Etats.

Ce volume publie des exposés relatifs à l'Asie-Pacifique présentés en 1989 et 1990 aux étudiants d'un troisième cycle d'enseignement universitaire, la maîtrise en politique internationale qu'organise le Centre d'études des Relations Internationales et Stratégiques (CERIS) de l'Université Libre de Bruxelles ${ }^{1}$.

Après une introduction générale aux problèmes de la région par M. Jacques Groothaert, qui a été le premier ambassadeur de Belgique en République populaire de Chine, M. Gérald Segal, Research Fellow au Royal Institute of International Affairs de Londres et éditeur de la "Pacific Review" analyse la politique de l'URSS à l'égard de ses voisins riverains du Pacifique sous l'impulsion de la nouvelle pensée diplomatique de M. M. Gorbatchev.

Madame I. Chuang Wu-Beyens, chercheur qualifié au FNRS et chargée de cours à l'UCL expose la voie suivie depuis 1978 pour réformer et accélérer le développement économique de la République populaire de Chine. Ce programme chinois des quatre modernisations qui a puisé son inspiration à plusieurs sources a notamment subi l'influence des succès remportés depuis une trentaine d'années par la Corée du Sud, Taiwan et Singapour. C'est à ces nouvelles économies industrialisées de l'Asie Pacifique qu'est consacrée l'étude de Madame Michèle Schmiegelow, chargée de cours à l'UCL. L'expérience menée par les "quatre dragons" d'Asie (l'expression englobe également 
Hong Kong) est élevée par Mme Schiegelow au rang de modèle à valeur universelle parce que basé sur des comportements rationnels et non pas sur des particularités de la culture extrême orientale; c'est le Japon qui en a frayé le chemin exemplaire.

S.E. M. Kato, ambassadeur du Japon à Bruxelles présente de manière synthétique la manière dont les Japonais voient les caractéristiques de la politique extérieure de leur pays alors que M. Ph. Debroux, professeur à l'Université de Okayama dresse un tableau des rapports économiques en Asie du Nord Est et du pivot que constitue le Japon en ce domaine.

M. Eric Philippart, directeur associé du CRIS à Bruxelles, reprend de manière critique les principales thèses émises à propos du bassin Pacifique qui pourrait assumer au siècle prochain le rôle central occupé par l'Océan Atlantique du 20ème siècle. M. Philippart, plus confiant dans l'avenir de l'Europe, ne croit pas à l'hégémonie prochaine du Pacifique dans le monde. Il voit plutôt se consolider un duopole nippo-américain et s'approfondir le clivage fondamental qui éloigne les nations riches des nations pauvres auxquelles les premières imposent des règles qu'elles seules fixent et interprètent.

Les décalages entre les périodes où ces textes ont été rédigés et les lacunes les plus criantes dans le tour d'horizon qui est brossé, sont partiellement corrigés par une chronologie qui rappelle les principaux événements survenus de 1988 à 1990 en Asie Pacifique mais aussi dans les relations est-ouest ainsi que les transformations vécues en Europe centrale et orientale. Cette chronologie informe sur les évolutions les plus récentes et met en évidence la pertinence des tendances fondamentales perçues par les différents auteurs des articles. 
Le contraste apparaît ainsi clairement entre la "maison commune européenne" qui émerge des ruines de la guerre froide et la persistance, en Asie orientale, de la glaciation. L'URSS saignée à blanc par la course aux armements, par son expansionnisme et par l'inefficacité de son système économique n'y inspire pas vraiment confiance et les principes définis par la Charte d'Helsinki pour l'Europe n'enthousiasment guère les dirigeants de l'Asie Orientale. Ni le gel des frontières définies à l'issue de la deuxième guerre mondiale, ni la renonciation à l'usage de la force pour régler les différends, ni la coopération et la détente dans le cadre d'une sécurité collective ne sont acceptés par les principales diplomaties de l'Asie orientale. Les disparités ne sont pas moins flagrantes entre la libéralisation économique, politique et culturelle des anciens tampons occidentaux de l'URSS et le renforcement des précautions contre tout dérapage dans les marches orientales après l'explosion du printemps 1989 en R.P. de Chine.

L'Année 1989 s'avère la période de tous les progrès en Europe; la croissance économique est continue, l'intégration du grand marché prend corps et le rideau de fer est aboli; la volonté des gouvernés s'exprime, l'esprit d'entreprise et le pluralisme reconquièrent droit de cité. Par contre en 1990, la crise du Moyen Orient expose la faiblesse de l'Europe, les conversations du GATT révèlent sa myopie, aucune leçon à usage intérieur n'est tirée des expériences vécues dans les pays qui cherchent à se libérer des monopoles étatiques et des entraves administratives au jeu des lois de l'économie; le désarroi de l'Europe orientale menace l'ouverture de la CEE aux peuples, la récession réduit la liberté des échanges et la "nouvelle pensée" soviétique dévoile sa fragilité.

En Asie orientale, les exigences de démocratie sont sauvagement réprimées. Le monopole idéologique détenu par le pouvoir politique est réaffirmé avec force et les droits des 
minorités restent ignorées, comme l'illustrent les exemples de la R.P. de Chine et de la Birmanie. La timide démocratisation annoncée en Corée du Sud semble paralysée par la peur qu'inspire le régime de la Corée du Nord.

La spectaculaire détente entre les Etats-Unis et l'URSS et la désintégration de la superpuissance soviétique ont privé les dirigeants du P.C. de Chine populaire du cadre qui leur a servi de référence depuis 1949. Il ne leur est plus possible de continuer à pencher autant qu'il leur paraissait nécessaire vers celle des deux superpuissances la moins immédiatement menaçante. Il faut à présent que le régime de Pékin saisisse à ses propres risques et périls les occasions propices qu'offre le nouvel ordre mondial et qu'il pare aux menaces qui en résultent, sans alliés et sans amis tactiques crédibles.

La réaction de la R.P. de Chine aux développements de la crise ouverte par l'invasion irakienne du Koweit confirme que ce qui préoccupe les dirigeants de Pékin est d'évaluer jusqu'à quel degré les Etats-Unis émergeront comme seule superpuissance, de supputer les rôles que tiendront l'Allemagne en Europe et le Japon en Asie-Pacifique en plus de leur rayonnement économique et de deviner quelle sera l'évolution de l'URSS et les conséquences qui en découleront.

Le durcissement soviétique que manifestent la tension en Lituanie et la démission de $\mathrm{M}$. Chevardnadze rassure peut-être les dirigeants de Pékin en ce qui concerne les probabilités de sécession des républiques soviétiques d'Asie centrale et leurs répercussions dans la Chine périphérique. Le rétablissement de l'ordre que veut Moscou par l'armée et les forces de la sûreté peut également susciter l'espoir de retrouver un allié idéologique de plus de poids que le Vietnam, la Corée du Nord et Cuba mais le retour à une politique soviétique dominée par le complexe militaro-industriel fait par ailleurs ressurgir le 
spectre de l'activisme soviétique à l'extérieur des frontières de l'Union. De plus, dans la recherche désespérée d'amis, la R.P. de Chine doit se tourner, comme l'URSS son ennemi le plus potentiellement dangereux, vers ceux des pays du tiers monde dans lesquels l'appel au volontarisme, les pulsions affectives et les promesses de fécondité de la violence restent plus mobilisateurs que les dures réalités des contraintes objectives et que le respect des règles internationales, encore longtemps sans doute soumises à l'interprétation, sinon à la définition par les pays les plus industrialisés.

Pas plus que la R.P. de Chine, le Japon ne croit à des accords de sécurité collective en Asie ni à un nouvel ordre mondial qui réglera tous les problèmes par l'application $\mathrm{du}$ droit international. Pour le maintien de la paix et de la sécurité dans la région, la présence des Etats-Unis reste indispensable, tant pour dissuader tout fauteur de trouble que pour rassurer les pays entraînés, pour leur développement économique, dans l'orbite du géant nippon.

La condition requise par Tokyo pour développer sa coopération avec l'URSS, à savoir la reconnaissance de la souveraineté japonaise sur les quatre Kouriles méridionales a de moins en moins de chance d'être satisfaite. Les dirigeants de l'URSS ne peuvent créer un précédent qui renforce les demandes de démembrement de l'Union; de plus l'autorité de fait sur ces territoires tend à échapper au pouvoir central pour passer aux mains de la République de Russie qui n'a pas de raison de céder des parcelles de son territoire contre des avantages au bénéfice de l'URSS toute entière.

De même que l'évolution interne d'un pays, la diplomatie peut emprunter plusieurs chemins et le renversement de 
dictatures vieillies n'implique pas nécessairement l'établissement d'un régime démocratique ni le respect de la sécurité régionale.

La reconnaissance de ce que les guerres sont évitables malgré la survivance de l'impérialisme n'assure pas qu'elles sont évitées parce que la volonté d'hégémonie ou de satisfaction d'intérêts immédiats n'est pas surmontée. La priorité à accorder au développement économique, social et intellectuel soit à des objectifs à long terme ne convainct pas les tenants du pouvoir qui craignent de ne pas récolter eux-mêmes le fruit de pareils efforts. Enfin, les sages ne parviennent que rarement à persuader l'ensemble des forces avec lesquelles ils doivent composer : les espoirs même les plus raisonnables ne sont jamais assurés d'être réalisés.

L'invocation d'une des dernières oeuvres de Paul Gauguin, l'une des plus marquantes aussi, à titre de patronnage du présent recueil ne tient pas seulement à ce qu'elle a été peinte aux Marquises, en plein coeur de l'Océan Pacifique. Comme l'artiste s'en est expliqué dans une lettre à son ami D. de Montfreid, "d'où venons-nous, qui sommes-nous, où allons nous ?" n'est pas le résultat de cartons préalables ni l'affirmation d'une école particulière de pensée : elle exprime une passion qui pour transmettre son message utilise une série d'images mûrement réfléchies qui jaillissent et s'ordonnent dans une quête infinie.

Les analyses distinctes de chacune des facettes abordées dans ce volume, dues à des spécialistes et donc nourries d'une connaissance intime de leur sujet, n'ont pas été soumises à un modèle imposé ni à des techniques ou à des règles communes définies au préalable. Loin de fournir une description exhaustive des problèmes de la région ni d'exprimer une théorie d'école, il s'agit d'éléments d'enseignement dont les lignes de 
force précisent les données de base qui conditionnent directement le destin d'un quart de l'humanité et indirectement celui du monde entier. L'ensemble justifié par la passion de connaissance que partagent les auteurs constitue un questionnement et ébauche des voies contradictoires de réponses quant aux problèmes que cherchent à résoudre les principaux pays de la région, quant aux objectifs recherchés, aux moyens utilisés et quant aux jalons qu'ils posent pour le 21ème siècle.

1. CERIS (Centre d'études des Relations Internationales et Stratégiques de l'U.L.B. - Avenue Roosevelt 50 - 1050 Bruxelles - C.P. 135). 
INTERNATIONAL RELATIONS IN THE WESTERN PACIFIC

Marthe ENGELBORGHS- BERTELS

Because of the economic expansion of Japan and the countries carried along in its wake, the part of the world where the Pacific Ocean washes the shores of Asia - often spoken of as the Asia-Pacific region - is seen as being destined to play a vital role not only as the motor of regional development and an example to emulate, but also as a future pole of decision in international affairs in conjunction with the eastern rim of the northern Pacific.

The present volume of "Civilisations" makes no attempt to describe a culture or a number of related cultures; rather, it analyses international relations in one huge area of the globe, the objectives pursued by the principal parties to them, and the means employed to attain them. If a civilisation is defined in terms of the values which determine the choices made by a culture from the range of methods available to it for exploiting the resources of the territory into which it breathes life, for organising its lebensraum, for providing a context for its people and for ensuring its continued existence, then everything relating to the way in which a country or group of countries strives to ensure its security, its independence and its power is obviously included in the title of our Journal.

What lies at the root of different foreign policies additionally modified by circumstances, by changes of leaders and by the degree of contentment of the peoples involved are domestic strategies centred sometimes on military force and sometimes on a nation's acquisition of the instruments of power through the blossoming of its economic and scientific potential 
and its choice of either a self-centred mode of development or of a turning to account of comparative advantages and worldwide interdependence. The results obtained from a given line of action determine the solidity, the survival and the influence of a state or a group of states.

The present volume contains a number of lectures on the Asia-Pacific region delivered in 1989 and 1990 to students preparing an MA in international politics at the Centre for the Study of International and Strategic Relations (CERIS) of the Université Libre de Bruxelles.

After a general introduction to the region's problems by Jacques Groothaert, Belgium's first ambassador to the People's Republic of China, Gerald Segal - a Research Fellow at the Royal Institute of International Affairs, London, and the editor of the "Pacific Review" - analyses the USSR's policy towards its Pacific neighbours in the light of M. M. Gorbachov's new diplomatic thinking.

The course taken since 1978 to reform and speed up economic development in the People's Republic of China is described by $\mathrm{l}$. Chuang Wu-Beyens, a distinguished researcher with the National Scientific Research Fund (FNRS) and a lecturer at the Universite Catholique de Louvain. While relying on a number of sources for its inspiration, China's programme of Four Modernisations has been particularly influenced by South Korea, Taiwan and Singapore's success over the last 30 years. And it is these new industrialised economies in the AsiaPacific region that form the subject of a study by Michèle Schmiegelow, who also lectures at the Université Catholique de Louvain. The experiment of the "Four Asian Dragons" (the term also includes Hong Kong) is elevated by Mme. Schmiegelow to the status of a universal value because it is 
based on rational behaviour and not on features peculiar to fareastern culture; Japan has shown the way.

His Excellency M. Kato, the Japanese Ambassador in Brussels, synthesises the way in which the Japanese see the characteristic features of their country's foreign policy while P. Debroux, a Professor at the University of Okayama, draws up a table covering economic relationships in north-east Asia and Japan as their hub.

Eric Philippart, associated director of CRISP, Brussels, takes a critical look at the principal arguments concerning the possibility of the Pacific basin assuming the central role in the coming century that has been played by the Atlantic in the present one. Displaying greater faith in Europe's future, Eric Philippart does not believe in the impending hegemony of the Pacific on the world scene. What he does see is the consolidation of the US-Japan axis and the growth of the fundamental divide between the rich and the poor nations, with the latter as the victims of rules which are propounded and interpreted by the former alone.

The different moments at which the various texts were written and the most flagrant shortcomings in the scene depicted are partly compensaded for by a time-scale which, in addition to the changes in Central and Eastern Europe, takes in the principal events in the Asia-Pacific region and in East-West relations over the $1988-1990$ period. This time-scale is a source of information on the most recent developments and brings out the relevance of the basic tendencies perceived by the different authors of the articles.

The contrast thus emerges clearly between the "common European house" which is appearing from the ruins of the cold war and the persistence of the ice-age in East Asia. Bled white 
by the arms race and by its expansionism and the inefficiency of its economic system, the USSR does not really inspire confidence; at the same time, the principles laid down for Europe in the Helsinki Agreement are hardly a cause of enthusiasm amongst East Asian leaders. Neither the freezing of the frontiers established at the outcome of the Second World War nor the renunciation of force to settle differences nor, indeed, cooperation and detente within the framework of a collective security system are accepted by the principal East Asian diplomacies. The disparities are no less crass between the economic, political and cultural liberalisation in the USSR's erstwhile buffer states in the West and the reinforcement of measures to prevent the situation getting out of hand on the eastern marches after the 1989 spring explosion in the People's Republic of China.

In Europe, 1989 saw progress on all fronts. Economic growth was non-stop, integration into the single market acquired substance and the Iron Curtain was swept away. The will of the ordinary people found expression and the spirit of enterprise and pluralism came into its own once again. By contrast, during the course of 1990 the Middle East crisis exposed Europe's weakness, the GATT talks demonstrated its short-sightedness and not one single lesson for domestic comsumption was derived from the experiences of the countries trying to shake off state monopolies and the administrative shackling of the laws of economics; the disarray in Eastern Europe threatened the opening up of the EEC to those countries, the recession reduced the freedom of trade and the "New Soviet Thinking" revealed its full fragility.

In East Asia, demands for democracy are savagely repressed. The ideological monopoly of those in power is forcibly reasserted and minority rights are still ignored witness the cases of Burma and the People's Republic of China. 
The timid move towards democracy ushered in South Korea seems paralysed by a fear of the North.

The spectacular thaw between the USA and the USSR and the disintegration of soviet super-power has deprived the leaders of the People's Republic of China of the framework that had served them since 1949. They can no longer continue leaning as far as deemed necessary in the direction of whichever of the two superpowers was the less menacing at the time. The Peking government must now stand on its own and seize the opportunities placed in its path by the new world order; at the same time, it must guard against any threats that might result while remaining devoid of either allies or credible tactical partners.

The reaction of the People's Republic of China to developments in the crisis provoked by the Iraki invasion of Kuwait confirms that the Peking leadership's main worry is firstly to arrive at an estimate of just how far the US will emerge as the sole superpower, secondly to calculate what roles will fall to Germany in Europe and Japan in the Asia-Pacific region in addition to their economic influence, and thirdly predict how the USSR will develop and what the consequences of this development will be.

The hardening of Soviet attitudes as shown by the tension in Lithuania and E. Shevardnadze's resignation will perhaps reassure the Peking leadership regarding the possibility of the secession of the soviet Central Asian republics and the repercussions of this on the Chinese periphery. The reestablishment of order sought by Moscow through the use of the army and the security forces may also give birth to the hope of once again finding an ideological ally with more clout than Vietnam, North Korea and Cuba; however, the Soviet return to a policy dominated by the military-industrial complex is also 
leading to the reappearance of the spectre of Soviet activism outside the Union. Moreover, in its desperate search for friends China, like the USSR - its potentially most dangerous enemy is having to turn to those Third World countries where an appeal to voluntarism, emotional pulsions and promises of fruition born of violence have a greater mobilising effect than either the hard realities of objective constraints or a respect for international rules whose interpretation, if not whose formulation, will be a matter for the most industrialised countries for many years to come.

Japan places no more faith than the People's Republic of China in collective security agreements in Asia or in a new world order that will settle disputes on the basis of international law. For the maintenance of peace and security in the region the presence of the US remains indispensable both to dissuade troublemakers and to reassure countries sucked into the orbit of the Japanese giant for their economic development.

Tokyo's condition for developing its cooperation with the USSR, namely the recognition of Japanese sovereignity over the southernmost four Kuriles, has less and less chance of being met. The Soviet leadership cannot create a precedent that would strengthen demands for the dismemberment of the Union; moreover, there is a tendency for the de facto authority over these territories to escape the central power and to pass into the hands of the Russian Republic, which has no reason to give up parts of its territory in exchange for advantages benefiting the USSR as a whole.

Diplomacy may follow various paths in a way similar to a country's domestic development, and the overturning of obsolescent dictatorships does not necessarily imply the estalishment of democratic government or a respect for regional security. 
The acknowledgement that wars can be avoided despite the survival of imperialism does not ensure that they are avoided because a desire for hegemony or for the satisfaction of immediate interests has not been surmounted. The priority to be granted to economic, social and intellectual development, i.e. to long-term objectives, does not win over those in power, who fear that they will not reap the fruits of such endeavours. And lastly, intellectual circles only rarely succeed in prevailing upon the forces with which they must come to terms; there is no guarantee that even the most reasonable of hopes will be satisfied.

The choice of one of Paul Gaugin's final and most outstanding works as the tutelar of our anthology is not simply due to the fact that it was painted in the heart of the Pacific, in the Marquesas. As the artist explained to his friend D. de Montfreid, "Where do we come from? Who are we ? Where are we going ?" is not the result of preparatory sketches or the statement of a particular school of thought. Rather, it is the expression of a passion which puts its message across by means of a series of well-thought-out images which pour forth and order themselves into an infinite quest.

The different analyses of each of the facets looked at in the present volume are the work of experts and so acquire breadth from their intimate knowledge of their subjects. There has been no imposition of set models or of pre-ordained and standardised methods and rules. Far from presenting a pioneering theory or an exhaustive description of the region's problems, what we are doing is offering teaching material whose lines of force specify the basic ideas which directly condition the fate of a quarter of humanity, and indirectly that of the whole world. Justified as it is by its authors' shared passion for knowledge, the present volume sketches out and questions the contradictory channels of response relating to the 
problems that the principal countries of the region are endeavouring to solve, the objectives sought, the means employed and the trail which these countries are blazing for the 21st. century. 